\title{
EXPRESSION OF RELIGION AND CULTURE OF KASEPUHAN CISUNGSANG CUSTOMARY COMMUNITY AT A PROCESSION OF PANTUN RECITATION OF RADEN GALUH PAKUAN PAJAJARAN IN THE SEREN TAUN CEREMONY
}

\author{
Mahmudah Nur \\ Puslitbang Lektur Khazanah Kegamaan dan Manajemen Organisasi \\ Jl. MH. Thamrin No.6, Menteng, Jakarta Pusat, Indonesia \\ E-mail:mahmudah.nur@kemenag.go.id
}

Article received February 22 $2^{\text {th }}, 2021$; Article revised April 1 ${ }^{\text {st }}, 2021$; Article approved May $8^{\text {th }}, 2021$

\begin{abstract}
Traditional pantun is one of series of events that still carried out in the Seren Taun ceremony in the Kasepuhan Cisungsang customary community. Pantun has a very important function for the customary community of Banten in particular and the Sundanese in general, which as a medium of communication, traditional knowledge of customary community, and a means of ritual as well. This study identified the forms of religious and cultural expressions in the traditional pantun tradition. This descriptive study employed qualitative data which aims to describe the form of acculturation of religion and culture in the pantun tradition. The folklore approach was used to analyze the story of pantun which is the focus of the discussion and related it to the cultural background of the Kasepuhan Cisungsang customary community. This study shows that the procession series of Seren Taun ceremony in Kasepuhan Cisungsang, plays a very important role in integrating the complex differences of view among modern society. Traditional pantun in a series of Seren Taun events become a source of knowledge and cultural expression of Kasepuhan Cisungsang customary community in order to maintain their traditions. The story of the RGPP pantun developed in the Cisungsang customary community is a real picture of their cosmology of life harmony with the natural environments, social and cultural environment.
\end{abstract}

Keywords: religious and cultural expressions of pantun, kasepuhan cisungsang, customary community, and seren taun.

\section{INTRODUCTION}

$\mathrm{P}$ antun tradition is one of the rituals carried out in Seren Taun ceremony by the komunitas Kesatuan Adat Banten Kidul (SABAKI) generally, and the Kasepuhan Cisungsang customary community particularly. Pantun develop orally from one person to another which belong to the community and become one of the Sundanese literary works of buhun (classical) legacy of the karuhun (ancestors). The definition of pantun according to the Kasepuhan Cisungsang customary community is different from the pant un tradition in Malay literature in general. Pantun in the tradition of the Kasepuhan community according to the definition of Rosidi (1996: 1) is a story or fairy tale that is quite long and can be performed all night long which is conveyed by the pantun specialist accompanied by the strings of kecapi. Pant un in such definition is one of the
Sundanese literary genres as the oldest original Sundanese literary form (Pudentia MPSS, 1992: 7). The definition of this pant un is different from the definition found in Malay literature which is a sentence structure consisting of sampiran and content of four or two lines. Studies on pantun have actually been done a lot, for example by Holle, Pleyte, Meyer and Hidding (Kartini, 1984: 1), unfortunately, until the 1900s there was not any satisfying and in-depth research on pant un stories yet.

Havelock (1986: 24) stated that there is a controversy from various points of view regarding studies of oral traditions because the tracking of orality itself is a paradox. It means that a text is unable to be studied before it exists. Yet according to Pudentia MPSS (1992: 9) that when the text is written, orality ends. Therefore, the difficulty faced in research on oral traditions is in reconstructing 
the oral version of the story, and rechecking the written version by listening to the speech of the pantun specialist. The tradition of pantun as an oral text that is rewritten without concerning on the written text related to the same theme as the result of oral literature has become an interesting issue to be raised in the research. A part from the content and meaning of the pantun, the dynamics of the speaker's life cannot be separated from the context of its development.

Rusyana (in Pudentia MPSS, 1992: 9) stated that in folklore, the speaker component is a very important element because it becomes an active supporter of the story. The pantun specialist has an important role in the pantun story. Unfortunately, several existing studies show that the present pantun composers are elderly and have no regeneration. As a result, there are concerns about the sustainability of the pantun story tradition. Thus, if there is a community that can still maintain that tradition well, then this fact shows the existence of community resilience in maintaining the traditions of their ancestors. Such resilience mechanisms can provide lessons for both the development and preservation of oral traditions in Indonesia.

One of the customary communities who still preserves and performes pantun is the Kasepuhan Cisungsang customary community. The practice is conducted by enlivening the Seren Taun tradition. Seren Taun is one of the traditional rituals performed annually which aims to honor the ancestors and as a form of gratitude to the god for giving the blessings and fertility. The Seren Taun ritual is one of a series of ceremonies in this traditional community of agriculte. According to Humaeni (2018: 2), this ceremony was attended by almost all elements of the Cisungsang customary community, Kasepuhan, rendangan, baris kolot, and all members of the customary community. This ceremony is led directly by the customary leader with a variety of activities. In a modern context, the ceremony which lasts for one week is filled with competitions, sports, entertainment, and ends with a traditional ceremonial ritual which is the culmination of a series of rituals contained in the Seren Taun ritual. This core ritual is usually held on Sunday mornings in front of Leuit Si Jimat, a traditional rice barn. Seren Taun's core rituals are now often attended by local governments, and eventually become one of the cultural icons and tourism icons of the Banten government.

In addition to the importance of the Seren Taun ritual, the pant un also has a very important function for the Cisungsang Kasepuhan customary community. It has become a medium of communication and transmission of traditional knowledge of indigenous peoples across generations (Permana, 2008: 1). If it is related to the custom, the pantun that is uttered in the ceremony or ritual is an absolute requirement that must exist, so that the harmony of a series of ceremonies or rituals is incomplete without pantun. Apart from that, the pantun also contains descriptions of customary rules, religion, and the life teachings that reinforce the traditions of Banten customary community. Pantun in the Seren Taun ritual is certainly part of the treasures of the archipelago's oral tradition which is meaningful.

Various types of oral traditions such as pantun have been studied by many researchers. Purnama (2005) in his study of the Panggung Karaton in the Situraja Sumedang community shows that the stage of pantun story consists of three parts, namely the rajah pamuka spell (opening), the story content, and again the rajah pamungkas spell (closing). The story contains of work, science, philosophy, social, politics, and power values. One of good example in it is the value of work shown and illustrated by the spirit (ethos) of Raden Layung Batik Panganginan's work in achieving goals. The results of different studies were found by Tini Kartini, Sutedja Sumadipura, Yetty Kusmiati, H., and Saini K.M (1980) who in their research stated that the structure of the pantun story consists of three elements, namely separation, tests (obstacles), and return. This research shows that the structure of the pant un story depicts the spiritual journey of the hero of the old Sundanese society. Although this research is more focused on the elements of the story, this information can provide a description of the author regarding the structure of the story. 
Studies conducted by Sudjamza (2006: 132) on the buhun giriwangi pantun found that the story of pant un, function in the ritual as well as entertainment for the community. As a means of ritual, this art is used in the procession of ruwatan (objects or humans) or the respondent of the pantun has a specific purpose in the show. While as a means of life, this art is used in thankfulness event or a form of gratitude event for the forty days of a newborn, wedding celebration, circumcision, and many other.

Permana (2008: 11) examines the Baduy pantun which reinforces the core tradition of the universe. This study shows that the pantun is one of the requirements for salvation activities in rituals to commemorate the life cycle, occupy a news house, or in agricultural processions. The contents of the pantun that are conveyed are descriptions and daily teachings of the Baduy people. The Baduy community does not recognize pantun related to certain kingdoms or famous figures as commonly found in West Java oral literat ure in general, such as panting about the Kingdom of Pajajaran, Pakuan, or the figures of Prabu Siliwangi, and etc.

If the previous studies tried to raise aspects of the use of pantun in various rituals, in 2017 the Jakarta Center for Religious Research and Development (Tarobin, 2017) studied the values of religious education in folklore. This research resulted in the finding that folklore can be used as a medium for religious education. One way is through adjusting the story or part of the story to become a more popular tool among students. However, in order to keep uniqueness of the character to be exist, the adaptation should keep presenting the story in its source language. Translations and explanations of the religious educational values contained in it should be conveyed with carefully. The goal is that students can get to know the culture better and able to improve the character. One of the studies in it also examines the story of the pant un of Sri Sadana / Sulanjana by Rosadi (Rosadi, 2017: 139).

Suryadi (1995) in his study of the role of the penyentangih, which is positioned as an pant un interpreter in the Kwangkay ceremony, the climax of the Dayak Benuaq death ceremony, reveals that in traditional society, often times, expressions of recognition of what is called "God" are manifested in the form of art. It shows that in a traditional society, arts and beliefs do not have a framework yet. In this event, the Penyetangih and Penuing have a role in the Kwangkay ceremony. Penyentangih is an oral poet who chants oral texts during the ceremony.

Penyentangih as though a thick book in a written tradition: the oral text in the mind of the penyentangih is information about the cultural journey of the Dayak Benuaq people. The essence of the oral text is a kind of communication between deceased spirits and living family members. In this case, penyentangih identifies himself as the spirit of the death, while at other times, he identifies himself as a member of the living family. Meanwhile, penuing is a penyentangih helper that support (the singing) at the end of each kouplet. Apart from their roles, the most urgent thing that must be done is to transfer the oral texts that are in the repertoire of the penyentangih into writing. If this is done too late, the "thick book" belonging to the Benuaq people which is meaningful would be disappeared from earth.

The diversity of above studies has portrayed many of the pantun and oral traditions in various regions. In particular, several studies related to Kasepuhan Cisungsang have also been carried out. Ulumi (2018: iii-iv), for example, examines the culture of the Kasepuhan Cisungsang community, including cultural identity, socioreligious rituals, traditions, customs, and the life view of the people. The same study was also carried out by Fadillah, et al (2015: 5659) regarding Mokaha Urang Cisungsang. The study says that the series of Seren Taun ceremonies have an important role as a means of integrating various differences of views that are getting complex in the midst of modern society.

The main problem raised in this paper is how the religious and cultural expressions of the Kasepuhan Cisungsang Lebak Banten society contained in the Raden Galuh Pakuan Pajajaran pantun in the Seren Taun ritual. Research related to pantun in Seren Taun ritual in the context of literacy and religion is important with two considerations. First, an understanding of religion in the local context. 
This consideration become strategic when faced with the process of increasing religious understanding and harmony between religious communities, as though the strategic plan for religious development at the Ministry of Religion (Iswanto, 2016: 104). In addition, as expressed by Zoetmulder (in Iswanto, 2017: 182) understanding of cultural peaks or forms cannot be achieved properly without understanding religious teachings, values, or ideas behind them which absorbed deeply. and form the culture. In addition, Parani (in Tarobin, 2016: 82) revealed that religious values are considered as very important in the realm of Malay cult ure, where this value is one of the three unifying knots that show identity apart from customs and language. Through these three knots, we can talk about insiders and outsiders, our people and other people.

Second, pantun is a tradition passed down from generation to generation which become the expression of the Kasepuhan customary community. The pantun tradition also contains certain messages, both in the form of social and religious values that are useful for the tradition followers and for public. Therefore, it is hoped that this study will not only take "communal spirituality" which can bind each individual to a certain group (Tarobin, 2016: 83). This value is expected to be used to bind the wider community, in the life of the nation and state.

\section{RESEARCH METHOD}

The collection of field data regarding cultural and religious phenomena in the Raden Galuh Pakuan Pajajaran pantun (later abbreviated as the RGPP pant un) in the Seren Taun ritual was lasted for 18 days in the Cisungsang customary community of Lebak Banten. In the process, data collection was conducted using interview techniques toward informants consisting of traditional elders and traditional practitioners. The information was then reinforced through observations on the implementation of the Seren Taun Ceremony and the ritual of the pantun performance. Likewise, literat ury studies related to history, demographic context, and the meaning of several aspects were also carried out carefully. This study used the approach suggested by Danandjaja (2015), that in the research of oral tradition matter, a 'folklore approach' can be used. The word 'folklore' contains elements of 'folk' (community collectivity) and 'lore' (tradition; partly culture passed down from generation to generation). Folklore consists of two elements: society and the traditions. Therefore, in the research of oral tradition, there are two elements that must be examined; society and culture along with the traditions which were passed down orally. Thus, the narrative content of the story in the pantun will be analyzed carefully by relate it to the cultural and religious aspects of the society who support the culture.

\section{DISCUSSION}

\section{Kasepuhan Cisungsang Customary Community}

Kasepuhan Cisungsang customary community are local people who live around the slopes of the Taman Nasional Gunung Halimun Salak (TNGHS) which is located at the southern tip of Banten Province, precisely in Lebak Regency and bordering Sukabumi Regency, West Java. The Kasepuhan Cisungsang customary community are in the area of Cisungsang Village, Cibeber District, Lebak Regency and part of the komunitas Kesatuan Adat Banten Kidul (SABAKI).

The word Cisungsang comes from the words "ci" and "sungsang". Ci (in Sundanese cai) means water, while sungsang in Sundanese means upside down or opposite from a familiar situation (Fadillah, 2015: 3233). Therefore, Cisungsang is defined as water flowing upstream (flowing in reverse). Another opinion says that "sungsang" is a kind of smelly and poisonous herbaceous plant. According to Fadillah (2015: 32), the "sungsang" plant (with the Latin name Gloriosa Superba. L) is shaped like an orchid and bright colored flowers. In Sundanese tradition, it is also stated that the naming of a village is usually derived from the name of the river and tree around the land area where the Sundanese people live.

Henriana Hatra, secretary of the Kasepuhan Cisungsang, said that there are three opinions/versions regarding the background of the Kasepuhan Cisungsang society. First, the Kasepuhan Cisungsang customary community were part of the troops of the Sunda Pajajaran Kingdom who escaped 
in 1579, as a result of the attack of the Sultanate of Banten led by Sultan Maulana Yusuf (see also Adimihardja, 1992: 22). They spread to two different areas, Mount Cibodas, Palasari, Jasinga, Bayah, Ujungkulon (Kasepuhan) and Lemah Parahyangan (Kanekes). Second, they were part of the Mataram royal troops who hid after the power of Mataram was handed over to the Dutch East Indies, then the VOC controlled the Halimun area. As said by Adolf Dingkler (Danasasmita, 1983: 9);

"... after the Batavia-Banten agreement in 1684, the population moved to the southern part of Batavia, which was said to be inhabitants, except for the remains of the Mataram Laskar who were hiding ..."

In addition, the Mount Halimun area became a base for the resistance of former members of Ki Tapa and Ratu Bagus Buang's troops while fighting against the $\mathrm{VOC}$ in the 18th century and calling himself as the Kasepuhan Pancer Mandiri (see also Malik, 2016: 77-79).

The third opinion, the Kasepuhan Cisungsang customary community was part of the Banten sultanate conflict between former troops and people who loyal to Sultan Ageng Tirtayasa. The area around Mount Halimun (Lebak and Bogor) became a guerrilla area during the prolonged war between Sultan Ageng Tirtayasa and his son Sult an Haji in the 17 th century. Two parties were involved in a power conflict resulting an independent group (Dienaputra, 2003: 125). Of the three opinions, the first opinion was most believed to be true, that they were part of the Sunda Pajajaran kingdom, they came from the descendants of King Siliwangi. This is also reflected in the various symbols, values, and beliefs held by the Kasepuhan Cisungsang customary community, such as the tradition of the pant un story in Seren Taun activities.

According to Baedhawy (2013: 132), the Kasepuhan Cisungsang is a religious community. This can be seen from the way they practice their daily rituals. The religion adhered by the people living in the Kasepuhan Cisungsang area was Islam, although some of the community members still practice the traditions or customs of their ancestors (karuhun). The language used, the place to live in, and the general customs which are still preserved make them categorized into the Sundanese ethnic group (Fadillah, 2015: 31).

Tatali paranti karuhun is a way of life that was strongly maintained and carried out by the Kasepuhan Cisungsang. These customary community have a view of life/philosophy/religious wisdom such as the adage "Tilu sapamulu, dua sakarupa, nu hiji eta keneh (three simultaneously, two similar, also that one thing)" (Baedhawy \& Wahyudin, 2013: 132-133). Tilu Sapamulu means religion, tradition and government must go side by side "Dua sakarupa" means that tradition and religion must run parallel, while nu hiji eta keneh means that everything must refer to the framework of the Unitary State of the Republic of Indonesia (NKRI). This means that religion, tradition, and government coexist in everyday life, as recorded in Figure 1.

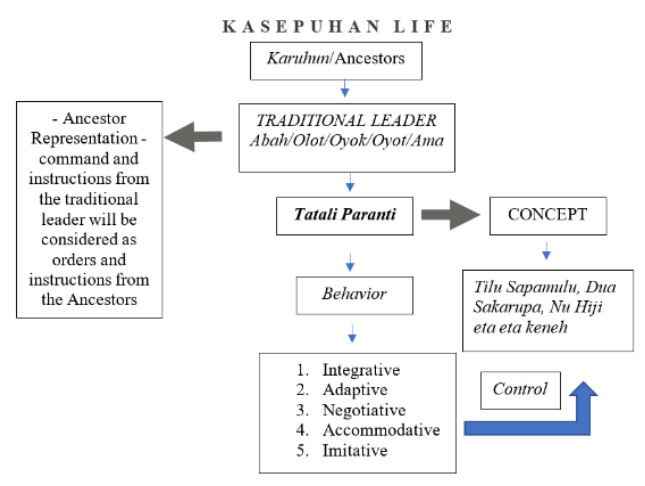

Figure 1.

Kasepuhan Cisungsang Community Structure

Regarding the Seren Taun event, the Cisungsang customary community believe that a harmonious life will be created if humans can maintain a balance between human and God, between human and each other, and between human and their natural environment. They also believe that temporal life is seen as buwana panca Tengah. This means that the human life cycle consists of the cycle of birth, life, and death to go to immortality in the afterlife. In simple terms, humans must prioritize pamodolan (defecating), thinking about pibututeun (fulfillling the need for clothing and material), and rawuh akhir (human will leave the world life). From this point of view, the land becomes important as a medium to fulfill the 
needs of life as well as a place for the growth of sri (rice) which can provide food to human.

As previously explained, there were Kasepuhan Cisungsang people who carry out and the customs or traditions of their ancestors (karuhun). It can be seen in Figure 1. that all traditional cycles that carried out were their responsibility towards the karuhun/ancestors. The customary leader represented as Abah/Olot/Oyok/Oyot/Ama is the highest leader in the Cisungsang Kasepuhan community, arguably as the top of the power pyramid who has expertise in agriculture (technical/symbolic), gives prayers and blessings for all activities carried out by Kasepuhan Cisungsang community. The governance carried out by Abah/Olot/Oyok/Oyot/Ama is centered on the tatali paranti karuhun described in the previous paragraph. The customary leader in the Kasepuhan Cisungsang community was a representation of the ancestors. Therefore, all orders and instructions from the customary leader will be considered as orders and instructions from the ancestors. Tatali paranti karuhun, a way of life carried out by the Kasepuhan Cisungsang community, becomes their control in the life cycle. These procedures shape the Kasepuhan Cisungsang community into an integrated, adaptive, negotiative, accommodative, and imitative society.

\section{Raden Galuh Pakuan Pajajaran Pantun as an Expression of Religion and Culture}

The pantun performance usually begins with delivering the opening of rajah and completed with the closing of rajah. The middle part of the story takes the form of dialogue and some are in the form of narrative (Rusyana, 1984: 71-85). In summary, the structure of the pantun story is divided into three parts, namely the opening rajah, the story, and the closing rajah (Abdulwahid, 1986: 31). However, Sastrawidjaja (in Purnama, 2016: 191) says that not all pantun story is closed with a closing-rajah. According to Purnama (2016: 191), the opening rajah is one type of spells intended as to request permission to karuhun (ancestors) or supernatural beings who control hills, upstream, rivers, mountains, huge trees, and places that are considered sacred. This is conducted in order to be safe and live without any obstacles in the way. Therefore, according to Pudentia (1992: 9) rajah functions as a repellent because it contains requests for permission and requests for refuge to the gods and ancestors to tell old stories that are considered sacred. The parts of the poetry story structure can also be seen in the transcription of the text.

The RGPP pantun was the one that often told in the Seren Taun ritual in Kasepuhan Cisungsang. The author quotes the name RGPP from the name of the character narrated in the pantun text. From the observation conducted on the contents of the pant un text, the writer did not find the same story, therefore the writer gave the title of this pantun as Raden Galuh Pakuan Pajajaran (RGPP). The RGPP pant un performance in the Seren Taun ritual is carried out at night, after Isha prayer until before Fajr. However, at this time, pant un performances were held about 3 to 4 hours after Isha. The poem told about the history of the origins of the Cisungsang customary community. According to Abah Apih Jampana (pant un performer) (interview, 2019), pantun known to the Cisungsang customary community as consisted of two forms. The first known as pantun sempal usually told for entertainment, such as the story of Malin Kundang and Si Kabayan. The second called pantun baluh, often performed in a Seren Taun ritual called bubuka pantun galur. Apih Jampana was chosen to perform the pant un in Seren Taun ritual since she was 16 years old. He did not know what was being told during the pantun tradition because he was chanting it unconsciously. The process of inheriting this pantun ability is also obtained through revelation (wangsit) and without any formal learning process. Therefore, no matter how hard a person learns to chant, if there is no revelation, he will not have the ability to chant.

The tradition of pantun in the Seren Taun Kasepuhan Cisungsang ritual is divided into three stages, first, the preparation stage which is the first part to prepare equipment and various materials for the ritual. Apih Jampana (Pantun practitioner) leads the preparations by presenting offerings (sesajen) as one of the conditions before the show begin. The offering (sesajen) is placed on a "nyiru" 
(tampah made of bamboo), which contains various types of food, cakes (wajik, dodol, uli, cucur, sagon, jipang, opak, etc.), ambon banana, and two glasses of water, to be prayed by Abah. The serving of this sesajen is believed to make the performance succeed and causes zero disaster. This offering was a sign of conditions to maintain harmony with ancestral spirits or spirits who come to the performance. This offering was also served for ancestral spirits, and humans, which contain symbols that understandable by human. These symbols are the reflection of human life, whether from symbols of purification, behavior, advice, self-awareness toward God, and so on (Sudjamza 2006, 39). In addition to its culture, which is full of religious values, Indonesia also has diversity in the culture that becomes the identity of its people. The acceptance of culture in religion gives birth to various cultural expressions. The diversity of Indonesian society, especially in terms of religion and culture, on the other side, provides the potential for the richness of Indonesia's cultural treasures, still, on the other hand, it also has the potential for disharmony.

Second, nyarita is an oral communication between the interpreter of the pantun and Abah or the person who has been given the task by Abah to receive "carita". Apih Jampana (Juru Pantun) went to Aki Edis (the person who was given the task by Abah) to ask for permission and the blessing in order to perform the pantun recitation. The tools and materials brought by Apih Jampana were "tumpang seupaheun" a type of sesajen, including cigarettes, sirih leaves, lime, panglay (bangle), and incense. Sitting face to face, Apih Jampana began this nyarita ritual by shaking hands, then conveyed the intentions and goals. Aki Edis listened carefully, then conveyed his agreement which was then filled with hopes and prayers so that the pantun ritual succeed. The musical instruments that accompany the ritual of the nyarita are the kecapi and flute. In addition, a pair of bound paddy placed in a "boboko" container made of bamboo and decorated with flowers, rurujakan (bitter coffee, water, milk, flower water), cigarettes and parupuyan (incense holder) in front of pantun practitioner.

Third, the stage of implementing the pantun ritual. This stage was divided into three parts; 1) Opening (incense burning, incense smoke) contains prayer asking permission from the Almighty God, a prayer asking permission from the ancestors, conveying the aims and objectives, submitting requests so that the ritual can run smoothly, praying for the ricefield, and praises songs to the god as well as rice as His creation. This was held in a way the person who brings "parupuyan" surrounding the pant un stage for 7 times. This step in the structure of the pant un story is called rajah (a kind of spell or prayer). According to Yus Rusyana, rajah is categorized as a spell that contains magic and passes down magical activity (1970: 11). The pronunciation of the rajah at the beginning of the mantun aims to apologize and requet permission from the spirits of the karuhun or ancestral spirits to be given fluency and safety in carrying out mantun. These habits usually carried out as a condition and duty before the story of pant un is being told. As contained in the opening text of the RGPP pantun rajah below:

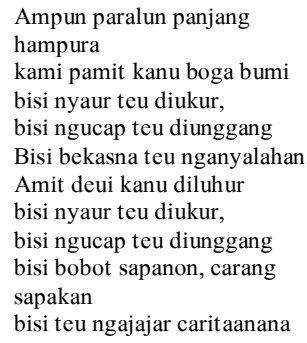

Ampun paralun panjang hampura

kami pamit kanu boga bumi bisi nyaur teu diukur,

bisi ngucap teu diunggang

Bisi bekasna teu nganyalahan

Amit deui kanu diluhur

bisi nyaur teu diukur,

bisi ngucap teu diunggang

bisi bobot sapanon, carang

sapakan

bisi teu ngajajar caritaanana

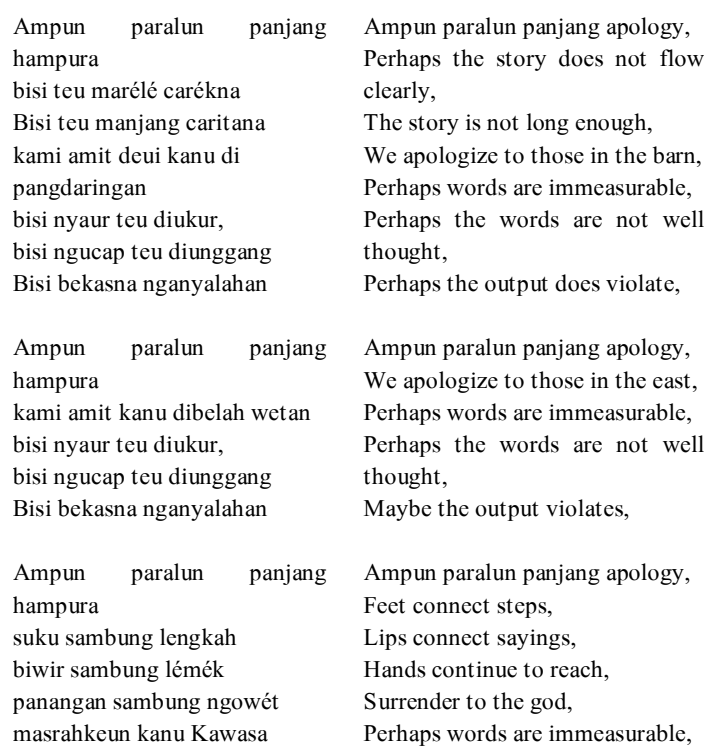

Ampun paralun panjang apology, We say goodbye to the owner of the house,

Perhaps words are immeasurable,

Perhaps the words are not well thought, violate,

mercy again to the god,

Perhaps words are immeasurable,

Perhaps the words are not well thought,

Perhaps the story does not flow clearly
Perhaps the output does not

Perhaps there is a shortage, 
bisi nyaur teu diukur, bisi ngucap teu diunggang

Perhaps the words are not well thought,

Ampun paralun panjang Ampun paralun panjang apology, hampura Perhaps the story is not long Bisi teu manjang caritana kami neda dimaklum bisi nyaur teu diukur, bisi ngucap teu diunggang menta hampura

suku sambung lengkah biwir sambung lemer panangan sambung ngowet enough,

We ask you to understand, Perhaps words are immeasurable, Perhaps the words are not well thought,

apologize

Feet connect steps,

Lips connect sayings,

Hands continue to reach,

Di dinya kami pasrahkeun deui sasajén

ka pangluhung hayang ditampi

Sri na, rurujakanana, kembangna nu tujuh rupa,

beasna sakuren, kalayan sangu, caina cai hérang, mangga nyanggakeun ..

nyanggakeun sadaya daya ....

ogé sasajénna

bisi kurang tina leuitna,

bisi kurang rurujakanana,

hampura...

Ampun paralun panjang Ampun paralun panjang apology, hampura Perhaps words are immeasurable,

bisi nyaur teu diukur, Perhaps the words are not well bisi ngucap teu diunggang thought,

Part (2), the carita pantun which contains the story of the journey of the ancestors begins with a situation in the wilderness accompanied by a kecapi, and occasionally the pantun practitioner lights a cigarette while the incense continues to burn and emits incense smoke during the ritual. This stage is a stage for the composer to tell the narrative of the pant un story accompanied by long dialogue as contained in the RGPP pant un text below:

di leuweung geledegan, cenah baheula,

poék mongkléng, teu katempo, nyumputkeun curuk curuk acan cenah baheula

nyalindung we dina kayu gede eweuh pisandingeunana

ngahuleng, ngalagameneng,

bingung,

kumaha kieu, aing aya dialam

dunya,

ngagilir ka belah kenca,

ngagilir ka belah katuhu,

aing kumaha ieu, aing aya di

leuweung luwang liwung

Nu Kawasa aing kumaha...

lieuk kaditu, lieuk kadieu

poék mongkléng

rék ngomong, ngomong jeun

saha

ngan ukur sorangan bingung teu manggih tungtung, susahna teu aya sudana, cara baheula Raden Galuh Pakuan Pajajaran

kumaha cenah aing ngan ukur hirup sorangan

mangkaning aing hirup kudu nyieun jalan

aing kumaha ngalaksanakeunana,

kumaha aing ngaléngkahna

rét ka katuhu, poék mongkléng

rét ka kenca mingkin komo

Di dinya mah munajat ka nu

Kawasa

ngahuleng ngaraga meneng

aing teu boga pibaturen, rek

jeung saha aing cacahan

$\mathrm{Nu}$ Kawasa.... coba menta

saciduh metu saucap nyata,

lamun aing ditakdirken hirup di

alam dunya

ieu aing lamun hirup, euweuh

batur rék kumaha

ahirna ...

di dinya mah .... kop baé kana

iteuk

na iteuk paku jagat

coba aing rek nyiptakeun

pibaturen

Raden Prabu Galuh Pakuan Pajajaran menta menta kanu

kawasa, hayang nyiptaken

manusa pibaturen, pikeun

nerusken lalakon

sakerak metrak, ngawujud manusa....

gejlig ka hareupeunana..

Amaaa,,, nyanggakeun sadayadaya

hmmm,,, sukur Sep ...

Nuhun nu Kawasa ... nuhun

kami geus dipercaya nyiptaken

manusa

Dialog :

“Ka dieu kasep ka dieu!”

"Amaaa,,mangga

nyanggakeun..."

"Sabab Ama euweuh pibaturen

keur hirup di alam dunya,

wayahna nu kasép jadi

pibatureun ama...

"Amaa...nyanggakeun sadaya

daya..

"ngen wayahna,, nu kasép kudu boga ngaran"

"nyaeta ngarana $\mathrm{Nu}$ kasép Léngsér"

Léngsér ngandung harti

kumaha diparentahna..."

"Nuhun... Ama.."

"Tong kajauh kasep.."

"Moal .. Ama"

"Ja ngan aya urang duaan"

"Sat ungt ung cukup pibatureun,

ulah waka kamana mana, urang

nyalindung baé dina kayu gedé."
Endless confusion, endless difficulty, like in the past Raden Galuh Pakuan Pajajaran

How is it, I just live alone, moreover I must make a way, How can I do it, how do I go Turned to the right, it was pitch dark,

To the left, the more so.

There is a place to pray to the god, to dream,

I do not have a potential companion, with whom I want to live with

The Lord, I ask for the miracle of your words,

If I'm destined to live in this world,

Even if I live, there's nothing else, I can't helped it,

Finally,

From there, then take a stick

paku jagat stick,

I' will make friend

Raden Prabu Galuh Pakuan Pajajaran ask to the Almighty, a need to create humans who will accompany him, to continue the story

One magic tap, human form, appeared before him,

Father... I surrender to give up everything

Hmmm. Thank goodness, son...

Thanks to the Almighty, thank you

I've been trusted to create humans

Come here, handsome, come here!

Father, I have come to your presence

"Because father does not have a companion in the world, so I beg you, Handsome, to be Rama's friend.

Rama, I obey all orders

But please understand, he must have a name

His name is, Lengser,

Leaving means surrendering

whatever you are ordered

Thank you Ama

Don't go far child

No Ama

Cause there's only the two of us As long as we have enough friends, don't go anywhere, we just hide in a big tree

Child, be good, let's make better future 
"kasép, sing hadé, urang nyieun kahirupan anu bakal datang"

"Léngsér," wayahna kudu nyiptaken deui manusa, teu cukup urang duaan..

Teras sujud kanu maha Kawasa, ngahuleng,

"Nu Kawasa, coba kami ménta manusa, sabab kami hirup teu cukup ku duaan

Ngan teu lila, kadéngé sora tanpa rupa

“Amaa,,, mangga nyanggakeun

(Am

"Urang geus boga batur,

wayahna tong kamana-mana

urang cicing heula...

Berarti urang geus aya tiluan...

Di dinya, munajat deui ka nu Kawasa,

sujud deui ...

ménta ka nu kawasa..

"Wayahna kami ménta dibaturan deui pikeun kami hirup di alam dunya"

Aya sora deui tanpa sora.

"Amaa,,,mangga

nyanggakeun,, Nu kasép ieu”

Urang ayeuna geus aya opatan

"Ayeuna kieu kasep... ku ama

rék ditugaskeun...

Ka belah wétan, ngan wayahna nu kasép ménta pingaraneun heula...

hayang boga ngaran ...

“Ama rék ménta ka nu kawasa, urang kudu bisa mawa batur

"Radén Tanjung Pamuka Alam, ngaranna"

"Hayang dijajapkeun ku Mang Léngsér.

"Léngsér,, jajapkeun ka belah wétan"

diiringkeun ku léngsér ka belah wétan

"mang Léngsér, ieu jalan ka belah wétan genah-genah teuing"

teu menang léwat ka belah dinya.

ieu wates, teu menang ngeleuleuwihi.

"Mang Léngsér rek mulang deui, laporan ka Ama yén nu kasep geus aya di belah wétan”

"Amaa,, parantos dijajapkeun, Radén Tanjung aya di tatar wétan"

"Anu kadua, ngarana Radén Perwira Jagad, anu cicing di belah kulon"
Lengser, I have to make another human again, both of us are not enough...

On kneel to the god, thinking

"Lord, we ask humans, because

living for only both of us are not good enough"

But not long after, a formless voice was heard

Ama..please

We already have friends, don't go anywhere, let's just calm down.

That means there are the three of

From there begged again to the Almighty,

bow down again,

Asking the Almighty

We ask for more companion gain to live in the natural world. There's another voice without a form

Amaaa... Ananda is in front of you

We are now four

Now, child... I want to assign you...

To the east, but please be advised to ask for a name first

wanting to have a name

Ama will ask the Almighty, we must be able to bring companions...

Raden Tanjung Pamuka Alam, it

Want to be delivered by Mang Lengser

Lengser, to the east.

Accompanied by Lengser down to the east.

Mang Lengser, this way to the east is very easy.

Can not gp from there

This is the border, cannot go through

Mang lengser wanted to go home, report to Ama that Ananda is already in the east.

Ama... it's done, Raden Tanjung is already in the east.

The second, named Raden Perwira Jagad, who lives in the west

took by Mang Lenger to the west

Ama, it's done, Raden Perwira Jagad is in West Tatar.
We will continue the journey,

"Diajajapkeun ku mang lengser ka belah kulon"

Raden Galuh Pakuan Pajajaran,

The Almighty, please forgive me

for a long time, I ask for more humans...

Contemplating....concentrating tatar Kulon"

urang terusken deui

lalampahanna, Radén Galuh

Pakuan Pajajaran,

$\mathrm{Nu}$ Kawasa, ampun paralun

panjang hampura, kula

nyuhunken deui manusa...

Ngahuleng,, ngaraga meneng...

Not long after, appeared beside

sagigireunana,,, sora awéwé... him, a female voice.

“Amaaaa,,,, masrahken sadaya Amaaa,,, I surrender completely

daya ... Nyai wants to be named soon

"Nyai hayang geura dibéré Nyai's name, Sri Mayangsari

ngaran" The Beauty of Sri Mayangsari will

"Nyai ngaranna, Sri be assigned to the south,

Mayangsari"

"Si Geulis Sri Mayangsari rék

ditugaskeun ka belah kidul"

Dijajap ku Mang Léngsér ka taken by Mang Lengser to the belah kidul. south

Ka patempatan anu genah To a place so comfortable

genah teuing Who made this place?

"Saha ieu an nyieun It is the Almighty work.

patempatan?

"Nu Kawasa anu nyieun"

Mun dipanggil iraha baé ku If at any time, whenever called by Ama, kudu datang, satungtung Ama, must come, as long as there is can aya panggilan ti Ama ulah no call from Ama, do not go. waka indit.

"Sajuru deui can kaeusian, juru One more is not filled yet, the belah kalér.. northern side..

"Urang ménta deui ka nu We ask again to the Almighty

Kawasa... Soon, granted by the Almighty, appear Raden Galuh Pakuan

Teu lila,,, dikobul ku nu Pajajaran

Kawasa,

Ka payuneun Raden Galuh

Pakuan Pajajaran ...

"Amaaaa,,, masrahken sadaya- Amaa,, I surrender myself daya ... completely

"Samemeh dibéré tugas ka Before being given an assignment belah kalér, ama rék méré to the north, Ama wanted to give papatah heula" advice.

"Nu kasép dibéré ngaran,,, Ananda was named... Raden Radén Perwira Buwana, nu Perwira Buwana who lived in the cicing di belah kalér. north

Dijajap ka belah kalér ku Mang Taken to the north by Mang

Léngsér. Lengser.

Ayeuna mah geus aya nu Now they are already in east, west, ngeusian, belah wétan kulon north and south.

kaler kidul

Raden Galuh sujud munajat ka Raden Galuh bow down and pray to anu kawasa, kami arék the Almighty, we will clean up ngabéréskeun patempatan, those places, whatever the naon baé persyaratanana. requirements.

Teu lila galapak wé,, hayam... Not long after, there is a chicken.

Raden Galuh ménta ka anu Raden Galuh ask the Almighty for kawasa keur katertiban order and safety in the hereafter for kasalametan dunya akhérat posterity. anak incu. 
Part 3) The closing contains prayer for the succesful of the ritual and an apology for missing things in the pant un ritual. Referring to the text of the RGPP pantun story above, some words or sentences show the values of religious education. However, things that need to be known and understood in analyzing a text of the RGPP pantun story cannot be interpreted textually only; there are many meanings contained in the text of the RGPP pantun story. According to Henri (interview, 9 September 2019), stories about RGPP are always recited in the Seren Taun stage at Kasepuhan Cisungsang. The story reminds the local community not to forget that they are descendants of the Pajajaran kingdom. In addition, the Kasepuhan Cisungsang wanted to show, as recorded in history, that in the 1400-1526 AD / 16th century Wahanten Girang or Banten Girang was under the control of Pajajaran (Guillot, 2008: 28). This is also confirmed in a Sundanese text, Carita Parahyangan, which states that the Pajajaran kingdom with its capital in Pakuan, which is now the city of Bogor, has succeeded in uniting all areas of West Java, from West, East, South to North under a single rule (Guillot, 2008: 28).

The Kasepuhan Cisungsang customary community is a religious society. Islam is followed by most of the local community, and there are also most people still carry out the traditions or customs of their ancestors (karuhun). The Seren Taun ceremony, a tradition carried out by their karuhun and passed down from one generation to the next, is one example of a tradition that is still being carried out. The religion referred to in this study is limited to Islam and the previous religions that they have believed in and shaped their religious life. Koentjaraningrat (1987: 80) stated that the belief system in a religion is manifested in human ideas concerning human beliefs and conceptions about the form of the supernatural, about the existence of nature and the world, about the afterlife and about the form of magical powers. This definition indicates that the Kasepuhan Cisungsang community is a religious community. Religious humans recognize sacredness, and it is this sacredness that ultimately gives birth to religious ceremonies in the form of worship (Miharja, 2015: 21).

Self-recognition as a Sundanese at the peak of Seren Taun's activities reveals that previously the religion and culture that formed it was the belief that is currently embraced by the Kanekes people. Djajadiningrat (in Ekadjati, 1995: 62) explains that the Kanekes are not Hindus, nor are they Buddhists, but rather believe in animism, a belief that worships the spirits of their ancestors. In addition, the Sundanese people at that time also had didactic books/texts, namely the Sanghyang Siksakandang Karesian script which contained guidance on norms, instructions, and moral lessons. The text can provide an overview of the broad moral guidelines for the sustainability of people's lives at that time, including the knowledge that must be mastered as a guideline for daily practical life. According to Danasasmita (1987: 6), the word Siskandang Karasian is a rule or teaching about the wisdom of life based on darma. Therefore, in analyzing the values of religious education in the RGPP pantun story can not be separated from the Sundanese religion and culture that shape it.

The expression of religious values in this study focuses on the structure of the pantun story in general and the text of the RGPP pantun story in particular which is divided into three structures, namely rajah pemuka, narrative, and rajah penutup. The religious expressions discussed in this study refer to the religion and culture of the Sundanese people. The expression of religious values in the first structure of the rajah opening of the RGPP pantun story shows the teachings of the dasa kreta; ten welfare that is achieved because of the ability to maintain ten sources of lust (Danasasmita \& Dkk, 1987: 9496). As stated in the previous paragraph about the opening of rajah in the RGPP pantun story.

The ten sources of lust are written in the script of Sanghyang Siksakandang Karesian (Danasasmita \& Dkk, 1987: 94-96). First, keep the ear from hearing which is not worth hearing because it becomes a door to disaster. The cause of getting harm is at the bottom of the blasphemy of hell, but if the ear is properly nourished it prioritize in hearing. Second, keep your eyes from seeing what is 
not worthy of being seen because that will be the door to disaster. If the eyes are properly preserved, the priority of sight is obtained. Third, do not feel restless because of heat or cold, because it is the door of disaster, the cause of our harm is at the bottom of hell's shame. If the skin is nourished, we will get the priority that comes from the skin.

Fourth, do not say something wrong because it is as if calling for disaster, the cause we get hurt at the bottom of hell's shame; but humans will get the priority that comes from speech if the speech is kept. Fifth, the nose should not be used to smell something wrong because it is the door of disaster that causes us to be harmed at the bottom of the shame of hell, but if the nose is nourished, we will get the virtue comes from the nose. Sixth, the mouth should not speak carelessly because it can bring disaster at the bottom of the blasphemy of hell; but if the mouth is kept. We will have the virtue that comes from the mouth. Seventh, hands are guarded not to take any things because they can bring disaster at the bottom of the blasphemy of hell; however, humans will receive priority that comes from the hand if the hand is kept.

Eighth, the feet should be kept from taking the wrong steps because they will lead to disaster, the cause of our harm is at the bottom of the shame of hell, we will get the virtue that comes from the feet if it is maintained in the path. Ninth, tumbung (anal hole/dubur and qubul) should not be used for keter (same-sex sexual relations such as homosexual or lesbian) because it is a door to disaster at the bottom of the blasphemy of hell; but if the tumbung is maintained, we will get the virtues that come from the tumbung. Tenth, the baga-purusa (Baga = female genitals, purusa $=$ male genitalia) should not be used for adultery, because it becomes the door of disaster, the cause of our harm is at the bottom of the blasphemy of hell, but if it is preserved, we will get the virtue from baga and purusa. If the ten doors (lust) have been maintained, the people will do well.

The Sundanese people are known as a society that prioritizes religious values, as embodied in the expressions of silih asih, silih asah, and silih asuh (loving one another, sharpening oneself, and caring for and protecting each other). Miharja (2015: 25) states that Sundanese people also have some other cultural values, namely politeness (handap asor), humility towards others, respect for older people, and love the younger (respect for ka nu luhur, nyaah ka nu leutik), helping those in need and those who are in distress (nulung ka nu butuh nalang ka nu susah). These cultural values can be seen in the first structure of the RGPP pantun story. As the quote from the RGPP pant un below:

\begin{tabular}{|c|c|}
\hline paralun panjang & ogy, \\
\hline $\begin{array}{l}\text { kami amit kanu dibelah wetan } \\
\text { bisi nyaur teu diukur, } \\
\text { bisi ngucap teu diunggang } \\
\text { Bisi bekasn nganyalahan }\end{array}$ & $\begin{array}{l}\text { Perhaps words are immeasurable, } \\
\text { perhaps the words are not well } \\
\text { thought, }\end{array}$ \\
\hline $\begin{array}{l}\text { Ampun paralun panjang } \\
\text { hampura } \\
\text { suku sambung lengkah } \\
\text { biwir sambung lémék } \\
\text { panangan sambung ngowét } \\
\text { masrahkeun kanu Kawasa } \\
\text { bisi nyaur teu diukur, } \\
\text { bisi ngucap teu diunggang }\end{array}$ & $\begin{array}{l}\text { Ampun paralun panjang apology, } \\
\text { feet join steps, } \\
\text { Lips conncet to sayings, } \\
\text { hands reach out, } \\
\text { Surrender to the Almighty, } \\
\text { Perhaps words are immeasurable, } \\
\text { perhaps the words are not well } \\
\text { thought, }\end{array}$ \\
\hline $\begin{array}{l}\text { Ampun paralun panjang } \\
\text { hampura }\end{array}$ & $\begin{array}{l}\text { Ampun paralun panjang apology, } \\
\text { Maybe not a long story }\end{array}$ \\
\hline $\begin{array}{l}\text { Bisi teu manjang caritana } \\
\text { kami neda dimaklum } \\
\text { bisi nyaur teu diukur, } \\
\text { bisi ngucap teu diunggang } \\
\text { menta hampura }\end{array}$ & $\begin{array}{l}\text { We ask you to understand, } \\
\text { Perhaps words are immeasurable, } \\
\text { perhaps the words are not well } \\
\text { thought out, } \\
\text { apologize }\end{array}$ \\
\hline
\end{tabular}

The expressions of religious values in the second structure, the narrative of the RGPP pantun story, shows the Sundanese people's belief in Buana Nyuncung (sky world), Buana Panca Tengah (earth world), and Buana Larang (hell) or what is commonly called the "triple pattern/pola tiga". In the narrative, it is shown that Raden Galuh Pakuan Pajajaran is someone who came from the heavenly world who was sent to earth to live his life. Like the RGPP text below:

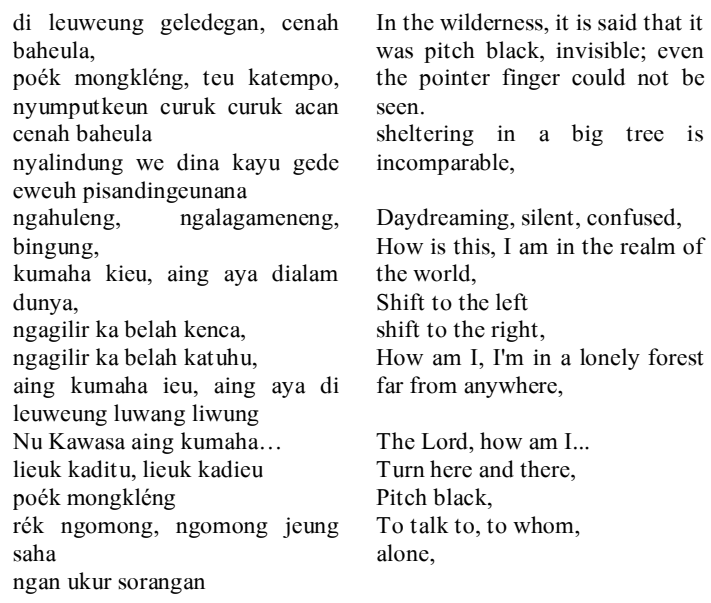


bingung teu manggih tungtung, Endless confusion, endless susahna teu aya sudana, cara difficulty, like in the past, Raden baheula Raden Galuh Pakuan Galuh Pakuan Pajajaran Pajajaran

In addition, it is also shown in the narrative of the opening rajah text that the pantun practitioner "apologizes again to the god" which means that they believe in the rulers of the heavens which is God. Like the RGPP text below:

$\begin{array}{ll}\begin{array}{l}\text { Ampun paralun panjang } \\ \text { hampura } \\ \text { kami pamit kanu boga bumi } \\ \text { bisi nyaur teu diukur, } \\ \text { bisi ngucap teu diunggang }\end{array} & \begin{array}{l}\text { Ampun paralun panjang apology, } \\ \text { We say goodbye to the owner of } \\ \text { the house, }\end{array} \\ \begin{array}{l}\text { Bisi bekasna teu nganyalahan } \\ \text { Amit deui kanu diluhur }\end{array} & \begin{array}{l}\text { perhaps the words are not well } \\ \text { thought out, }\end{array} \\ \text { bisi nyaur teu diukur, } & \begin{array}{l}\text { Perhaps the outcome did not } \\ \text { violate, } \\ \text { bisi ngucap teu diunggang } \\ \text { bisi bobot sapanon, carang } \\ \text { sapakan }\end{array} \\ \text { bisi teu ngajajar caritaanana } & \begin{array}{l}\text { Perhaps words are immeasurable, } \\ \text { perhaps the words are not well } \\ \text { thought out, } \\ \text { Maybe there's a shortage }\end{array} \\ & \begin{array}{l}\text { Maybe the story is not stated } \\ \text { clearly }\end{array}\end{array}$

The Seren Taun ritual is a tribute to "Nyi Pohaci Sang Hyang Sri, Princess Dewi Anta." Nyi Pohaci Sang Hyang Sri is a figure of a rice goddess who is respected and worshiped in a religious-magical Seren Taun event (Malik, 2016: 151). This story became one of a series of events that were told and carried out at the peak of Seren Taun Kasepuhan Cisungsang. The narrative tells the story so that the local community can handle the rice as well as possible, as appropriate to treat honorable princesses and have supernatural powers, from the process of planting seeds, during plant maintenance, stalk harvesting, to storing time in the barn. This story implies that apart from maintaining a relationship with God (habluminallah), the Cisungsang customary community must also maintain relationships with other creatures (habluminannas).

It is also told in the narrative structure of the RGPP pantun story about Raden Galuh Pakuan Pajajaran's mission of building roads. This mission in the Sanghyang Siksakandang Karesian script (Danasasmita \& Dkk, 1987: 97-98) is called our way of serving the Lord of the heavens, which means that work is the fut ure of the mind, the behavior itself is the way. The path of serving is understood as wuku lima called, purwa, daksina, pasima, utara, and madya. Purba is east, where Hyang Isora is shown by the figure of Raden Tanjung Pamuka Alam who was sent by Raden Galuh

Pakuan Pajajaran to the east. Daksina is south of Hyang Brahma's place shown by the figure Sri Mayangsari. Pasima is west, where Hyang Mahadeva is shown by the figure of Raden Perwira Jagad. Utara is north, where Hyang Wisnu is shown by the figure of Raden Perwira Buwana. Meanwhile, Madya itself is in the middle of Hyang Siwa's place, shown by the figure of Raden Galuh Pakuan Pajajaran.

Wuku lima above is a welfare capital which means that the secret will be felt in speaking, tapa will be felt in wandering, sitting will be felt in firmness, certainty will be felt in the impossibility, the release will be felt in giving without being given, remembering (eling) there is no set of limit . All these names represent one's own name, one must look at oneself, if one does not see oneself as crooked meets crooked, straight meets straight. This means because human actions will be prosperous because human actions.

kumaha cenah aing ngan ukur hirup sorangan

mangkaning aing hirup kudu nyieun jalan

aing kumaha ngalaksanakeunana, kumaha aing ngaléngkahna rét ka katuhu, poék mongkléng rét ka kenca mingkin komo

hmmm...lamun kieu mah aing geus dipercayakeun ku anu Kawasa.. ges kieu mah kapalang

kapalang tanggung aing geus kieu mah

Di dinya mah munajat ka nu Kawasa ngahuleng ngaraga meneng

aing teu boga pibaturen, rek jeung saha aing cacahan

Nu Kawasa.... coba menta saciduh metu saucap nyata,

lamun aing ditakdirken hirup di alam dunya

ieu aing lamun hirup, euweuh batur rék kumaha

ahirna ...

di dinya mah .... kop baé kana iteuk na iteuk paku jagat

coba aing rek nyiptakeun pibaturen

Raden Prabu Galuh Pakuan Pajajaran menta menta kanu kawasa, hayang nyiptaken manusa pibaturen, pikeun nerusken lalakon
How is it, I just live alone I have to make my way, How can I do it, how do I go Turned to the right, it was pitch dark,

To the left, the more.

Hmmm, if so I have been trusted by the Almighty, If that's the case, then It's better be done.

There is a place to pray to the mighty, to dream,

don't have a potential companion, with whom I want to live with

Lord, I ask for the miracle of your words,

If I'm destined to live in this world,

Even if I live, there's nothing else, I can't helped it,

Finally,

From there, then take a stick stick of paku jagat, I'll make friend Raden Prabu Galuh Pakuan Pajajaran asking the Almighty, wanting to create a human who will accompany him, to continue the story 


\section{CLOSING}

The series of Seren Taun ceremonies at Kasepuhan Cisungsang have an important role in integrating various differences of views that are increasingly complex in the midst of modern society. The tradition of traditional pantun as one of the stages in the series of Seren Taun events is evidence of the source of knowledge and cultural expressions of the Kasepuhan Cisungsang community to maintain continuity of their traditions. This can be seen in the preparation stages of the pantun tradition which is viscous toward the customs and culture of their ancestors.

The story of the RGPP pantun developed in the Cisungsang indigenous community is a real picture of their cosmological view of life in harmony with the nat ural environment, the social environment, and the cultural environment. This is shown by the text of the RGPP pantun which contains the concept of human creation on earth which is an important chronicle in the traditions of Sundanese society, life and social history, and also life advice. In addition, this pant un tradition serves as a reminder of the Cisungsang customary community of the norms prevailing in their environment and the origin of the Cisungsang customary community.

The text of the RGPP pant un reflects a harmonious view of life patterns to implement customary, religious, and state laws. This is in line with the definition of the values of religious education in this study, namely the rules of life that are accepted as knowledge to shape attitudes, personalities, and skills in practicing their religious teachings to become Indonesian people who believe and fear God showing noble character and maintaining the peace and harmony among religious believers. These values consist of: (1) worshiping in line with the belief; (2) doing good deeds; (3) maintaining peace and harmony.

\section{ACKNOWLEDGEMENT}

The author would like to thank Abah Usep Suyatna (head of the Cisungsang customary community), Henriana Hatra (Secretary of the Cisungsang customary community), Apih Jampana (a pant un for the
Cisungsang customary community), Helmy

Faizi Bahrul Ulumi (Director of Bantenology), and Aditia Gunawan (Manuscript Philologist of Sundanese manuscripts from the National Library of the Republic of Indonesia) which have assisted and provided input on this study. Also, thanks to the scholars and writers who have helped in the process.

\section{REFERENCES}

Abdul wahid, idat. (1986). Aspek Filosofis Cerita Pantun Mundinglaya Di Kusuma. Fakultas Sastra Universitas Padjadjaran.

Adimihardja, K. (1992). Kasepuhan yang tumbuh di atas yang luruh : pengelolaan lingkungan secara tradisional di kawasan Gunung Halimun Jawa Barat. Tarsito. https://catalog.hathitrust.org/Record/0 10172373

Baedhawy, R. ., \& Wahyudin, N. (2013). Nilai-nilai Kearifan Lokal dalam Pelestarian Lingkungan Hidup Masyarakat Baduy dan Kasepuhan Cisungsang. Dinas Kebudayaan dan Pariwisata Provinsi Banten.

Danandjaja, J. (2015). Pendekatan Folklor dalam Penelitian Bahan-bahan Tradisi Lisan. In Metodologi Kajian Tradisi Lisan, edisi revisi (p. 542). Yayasan Pustaka Obor Indonesia.

Danasasmita, S. (1983). Sejarah Bogor Volume 1. Pemerintah daerah Kotamadya DI II.

Danasasmita, S., \& Dkk. (1987). Sewaka Darma, Sanghyang siksakandang karesian, Amanat galunggung : Transkripsi dan terjemahan. Proyek Penelitian dan Pengkajian Kebudayaan Sunda (Sundanologi), Direktorat Jenderal Kebudayaan.

Dienaputra, R. (2003). Kebudayaan Sunda: antara Mitos dan Realitas. Menggugat Budaya Sunda: Persfektif Periferal.

Ekadjati, E. S. (1995). Kebudayaan Sunda (Suatu Pendekatan Sejarah). Dunia Pustaka Jaya.

Fadillah, M. A. D. (2015). Mengenal Masyarakat Adat Banten Kidul: 
Mokaha Urang Cisungsang. Penerbit Dinas Kebudayaan Pariwisata Provinsi Banten.

Guillot, C. (2008). Banten: Sejarah dan Peradaban Abad X-XVII. Kepustakaan Populer Gramedia (KPG), Ecole Francaise d'Extreme-orient (EFEO), dan Pusat Penelitian dan Pengembangan Arkeologi Nasional.

Havelock, E. A. (1986). The Muse Leams to Write: Reflections on Orality andLiteracy from Antiquity to the Present. Yale University Press. https://doi.org/10.1093/nq/ns-34.4.512

Humaeni, A. (2018). Ritual Seren Taun Di Kasepuhan Cisungsang Lebak Banten. Nilai-Nilai Budaya Dan Agama Dalam Tradisi Ritual Masyarakat Di Indonesia Bagian Barat.

Iswanto, A. (2016). Nilai-Nilai Keagamaan dan Kerukunan dalam Tradisi Warahan di Lampung. In Nilai-Nilai Keagamaan dan Kerukunan dalam Tradisi Lisan Nusantara (p. 286).

Iswanto, A. (2017). Building Harmony Through Religious Reception In Culture: Lesson Learned From Radin Jambat Folktale Of Lampung. Analisa Journal of Science and Religion, 2(2), 182-197.

Kartini, T. dkk. (1980). Struktur Cerita Pantun Sunda.

Kartini, T. dkk. (1984). Struktur Cerita Pantun Sunda: Alur.

Koentjaraningrat. (1987). Sejarah Teori Antropologi 1. Universitas Indonesia Press.

Malik, A. (2016). Berjuang Menegakkan Eksistensi. Biro Humas dan Protokol Setda Provinsi Banten.

Miharja, D. (2015). Deni Miharja, Sistem Kepercayaan Awal...... 19-36.

Permana, R. C. E. (2008). Pantun Baduy Pengukuh Tradisi Inti Jagat. Seminar Internasional Tradisi Lisan Nusantara (Lisan VI), Lisan VI, 1-13.

Pudentia MPSS. (1992). Transformasi Sastra : Analisis Atas Cerita Rakyat " Lutung Kasarung ". Balai Pustaka.
Purnama, Y. (2005). Tradisi Lisan : Carita Pantun Panggung Karaton Pada Masyarakat Situraja Sumedang. Departemen Kebudayaan dan Pariwisata, Balai Kajian Sejarah dan Nilai Tradisional.

Purnama, Y. (2016). Kajian Nilai Budaya Dalam Carita Pant un Sawung Galing. Patanjala : Jurnal Penelitian Sejarah Dan Budaya, 8(2), 187. https://doi.org/10.30959/patanjala.v8i2 .72

Rosadi, M. (2017). Nilai-Nilai Pendidikan Agama dalam Cerita Pantun Sri Sadana/Sulanjana. In Nilai-Nilai Pendidikan Agama dalam Cerita Rakyat Daerah (p. 139). Balai Litbang Agama Jakarta, Kementerian Agama.

Rosidi, A. (1996). Kesusastraan Sunda Dewasa Ini. Tjupumanik.

Rusyana, Y. (1970). Bagbagan puisi mantra Sunda. Proyek Penelitian Pantun dan Foklor Sunda.

Rusyana, Y. (1984). Panyungsi sastra : pengajaran sastra Sunda pikeun murid sakola lanjutan [Wor. Gunung Larang.

Sudjamza, A. P. (2006). Pantun Buhun Giriwangi di desa Baros Kecamatan Arjasari Banjaran Kabupaten Bandung. Sekolah Tinggi Seni Indonesia Jurusan Karawitan.

Suryadi, D. (1995). Dimensi tradisi lisan dalam upacara kwangkay : puncak upacara kematian suku dayak benuaq.

Tarobin, M. (2016). Nilai Keagamaan dan Kerukunan dalam Teater Rakyat "Mendu" di Natunan. In Nilai-Nilai Keagamaan dan Kerukunan dalam Tradisi Lisan Nusantara (p. 286). Balai Litbang Agama Jakarta, Kementerian Agama.

Tarobin, M. dkk. (2017). Nilai-Nilai Pendidikan Agama dalam Cerita Rakyat Daerah. Balai Litbang Agama Jakarta, Kementerian Agama.

Ulumi, H. F. B. (2018). Budaya Masyarakat Kasepuhan Cisungsang (A. Humaeni (ed.); Pertama). 